\title{
President Joko Widodo's Rhetorical Technique of Arguing in the Presidential Speeches of the Reform Era
}

\author{
Noermanzah ${ }^{1 *}$, Emzir $^{2}$, Ninuk Lustyantie ${ }^{2}$ \\ ${ }^{1}$ Indonesia Language Education Study Program, STKIP PGRI Lubuklinggau, PO box 31628, Air Kuti Street, Lubuklinggau City, Indonesia, \\ ${ }^{2}$ Applied Linguistics Doctoral Program, Jakarta State University (UNJ), PO box 13220, Rawamangun Muka Street, East Jakarta, Indonesia \\ Corresponding Author: Abeer Ahmad Moh`d Khatatbeh, E-mail: abeerahmad261@yahoo.com
}

\begin{tabular}{l} 
ARTICLE INFO \\
\hline Article history \\
Received: March 12, 2018 \\
Accepted: May 09, 2018 \\
Published: September 01, 2018 \\
Volume: 7 Issue: 5 \\
Advance access: July 2018 \\
\hline
\end{tabular}

Conflicts of interest: None

Funding: The research is

financed by DRPM Ditjen

Penguatan Risbang

Kemenristekdikti RI

\begin{abstract}
A good speech has the power in presenting the rhetorical argument, therefore it is required a study corresponds to the speech preparation with rhetorical techniques to argue, especially in the presidential speech of the President of the Republic of Indonesia Joko Widodo of reform era in the field of education. The research method was the critical discourse analysis method of Norman Fairclough model. Data collection techniques used were documentation techniques, note-taking techniques, and interviews. Data analysis techniques were administered by connecting micro, meso, and macro elements in dimensions: (a) text, (b) discourse practice, and (b) socio-cultural practices. The results show that President Joko Widodo and his team used the argument technique: 1) The introduction has two patterns: (a) claim and ground; and (b) claims. 2) The trunk or content section has a pattern: (a) claim and ground; (b) claim, ground, and claim; (c) claim, ground, and warrant; (d) claim, ground, and possible; and (e) claim, ground, warrant and backing with each sub topic or argument, minimally and dominantly comprising claim and ground. 3) The closing section has a pattern: (a) claim, ground, and claim; (b) claim. The rhetorical technique of arguing in a presidential speech aims at explaining the plans of educational programs, undertaken educational programs, and the promise and expectation to improve the quality of education in Indonesia during the reform era.
\end{abstract}

Key words: Rhetorical Techniques Of Arguing; Presidential Speech, Reform Era

\section{INTRODUCTION}

Language competence related to language activity as an activity that never separated in human life. This language activity can be demonstrated by how capable language learners are in mastering language skills. According to Aydoğan and Akbarov (2014:673), these language skills can be both macro and micro. Macro or basic language skill includs listening, speaking, reading, and speaking. Micro language skill includs grammar, vocabulary, pronunciation, and spelling. The four macro skills, related to each other with two parameters, are (1) communication mode: oral or written and (2) communication direction: receiving or generating messages. Thus, to communicate and socialize, language functions ideational and interpersonal, while to realize or realize the discourse, the language works textually.

Discourse is generally used both in oral and verbal communication as well as written. According to Walace Chafe (in Renkema, 2004:65) the differences in using of both discourses are: (1) writing takes a longer time than talking, (2) the author has no direct contact with the reader, (3) the integration in oral communication is not bounded by rules, (4) integration in written communication is bounded to rules which are contradictory to fragmentation by using more subordinate conjunctions. Verbal interaction is a mutual agreement between the speaker (communicator) and the listener (communicant) through language information and non-language information such as intonation, hand gestures, and others. For that, the type of discourse that uses oral communication media requires special techniques from the speaker in packaging the discourse that will be delivered. One oral communication that requires special techniques is the activity of speech.

Presidential speeches are as a means of communication as a tool of political communication particularly, it should be envisaged the political elements that surround and underlie speech activities. It is a custom that every political leader, men in power, and politicians always harness the power of language to strengthen consolidation in order to maintain its continued power. Therefore, the political communication which is ruled cannot be separated from the use of language, terms, verbal symbols, which focuses on certain topic and aspect. The use of terms, words, sentences can direct audiences to certain thoughts and feelings, and may even affect 
their behavior. Certain lexicon, for example, selected by government officials to emphasize political attitudes and opinions, assembled supports, manipulate public opinion, construct public political consciousness or legitimacy of political power (Jupriono, 2010:38-39). Thus, a communicator may select the topic of conversation, choose a particular discourse background, use certain rhetorical techniques, compose and organize speeches, use certain interactions, etc. therefore the delivered speech is able to persuade the audiences.

Presidential speeches have an important position in political discourse. Everything that president says has more influence on society than any other speech. The president's speech always refers public policy, what the president saying is considered as an important issue by the government. The presidential speech also influences how society thinks about existing socio-political realities (Eriyanto, 2000:16). Among the various speeches, the presidential speeches occupy a very important position. The presidential speech has developed into a regular pattern or form, which provides a useful basis for comparing speeches with one another. Hamilton (2012:xii-vv) explains the three forms of speech: informative speech, persuasive speech, both in individual and individual form, persuasive speech using theoretical methods and concepts, and speeches at special events. The presidential speeches in this case refer to the opinion of Hamilton and it is compiled in some state events.

Aristotle (in Rachmat, 2014:6-8) explains that there are five stages in the process of preparing a speech with special preparation or better known as the Five Rhetorical Laws. They are discovery, composition, style, memory, and delivery. Public speech in general is also arranged through these stages. In the process of preparing the presidential speech it is indirectly through the process of arranging the language effectively or better known as the rhetorical skill. As president in the reform era, President Joko Widodo has the characteristics in the rhetoric, especially in the speech. Results of research which was conducted by Noermanzah (2016:2223) presented the use of rhetorical patterns in his presidential speech with preliminary/introduction structures, torso, and conclusions. The introductory section consists of opening utterances, drawings and transitions that have a rhetorical function of respecting the participants, drawing the listener's attention with narration, comparison with the conditions of other countries, giving examples, introducing the body of the topic of Pancasila with exposition. In the body section, consists of arguments, explanations, quotations, illustrations, applications, requests, statements that have a rhetorical function of strengthening, definitions, objective data, sampling, and motivation to the listener. Then, the conclusion consists of invitations, conclusions, prayers, pleas, and concluding signs that have some rhetorical functions in the form of definitions, expectations, following government decisions, salutations, and prayers to listeners.

Furthermore, the interesting characteristic of President Joko Widodo's rhetoric was delivered by Ricky (2014) from his research in 2014 presidential debate speech, in terms of the use of ethos, patos and logos. In the use of ethos, President Joko Widodo is a simple man, society supporter, a coun- try man, and down-to-earth person. The use of patos, Joko Widodo uses the facts he found when doing impromptu visit to improve his audience sympathy. Then the use of logos, Joko Widodo uses the facts of the program about Healthy Indonesia Card, and Indonesia Smart Card as a concrete proof of some programs that he does.

The reform era run by the government has an impact primarily in the field of education with the policies announced or informed through the presidential speech. Indonesia's national education in the twenty-first century faces tremendous challenges, including the challenge of globalization, regional autonomy, and decentralization of education to develop education which relevant to the living environments of citizens of learning and supported by their communities. The results of a survey which was conducted by The Political and Economic Risk Consultancy (PERC) of Hong Kong indicates that Indonesia's education system is ranked $12^{\text {th }}$ in Asia, after Vietnam, with South Korea and Singapore at the first and second place (Nur, 2001:v). The results of this survey are based on the low quality of labor related to the low quality of the education system.

Indonesia is still in the transition process with a movement to give greater autonomy to the regions, although many are still unsure and doubtful, this change may have the desired impact and results. This hesitancy appears due to some reasons such as, some countries that have long been educated with decentralized management desired to return to the management of centralization, especially in the field of education. It was proved by the implementation of decentralization; Indonesia is still in a condition that its education system is still lagging behind other developing countries in Asia.

From several programs that have been and may be implemented by President Joko Widodo, it needs to be discussed thoroughly how effectively the power of rhetorical technique of Joko Widodo in his speech, particularly associated to his presidential speech in the field of education. This may show how consistent the rhetoric techniques are structured and the implementation of the rhetoric, thus it may provide information that President Joko Widodo's rhetoric is truly used as a means for implementing his programs or simply as a mere rhetorical that lack of empirical evidence in society.

Winkler and McCueen (1974:5-6) explain the opinion of Aristotle that rhetoric is an intelligent ability to use the means available in every problem in the process of persuasion. Then, Altikriti (2016:63) explains that in applying rhetoric especially rhetoric in political discourse, in influencing the listener directly and indirectly, it can used various means of utterance of more than one act of illocution. This illustration is an utterance that has a function as a tool to declare an information and at the same time give impact to do something action or action to the listener. One means of persuasion is the technique of persuasion. This can be in the form of argument techniques because arguments are a part of persuasive and persuasive is a central feature of speech rhetoric.

McCrimmon (1984:329-343) argues that persuasion is a verbal communication that can lead to voluntary change in judgment, so that others will accept different beliefs. The purpose of persuasion is to change the thoughts, beliefs, or actions of others or audiences. This change must be volun- 
tary. It means that those who are persecuted must be free to accept or reject the belief. One way of persuasion is to show others how we reach conclusions. The three things that must exist in persuasion are the belief (knowledge and honesty) of the reader or listener to the speaker or author, emotional appeal, and convincing through logical arguments. McCrimmon also said that the argument is the relation between statement and conclusion. Thus, one must provide a logical argument for a persuasive purpose to be achieved well. In the logical process of argument reasoning, it is usually related to the idea of cause, consequence, category, or alternative (Winkler and McCueen, 1974: 139-140).

Crusus and Chanel (2003:15-18) explain the argument as mature reasoning. Reasoning here means an opinion plus a reason (or reason to support that opinion). The objectives of Crusus and Chanel arguments include: (1) addressing a question, problem, or issue (usually part of the research process); (2) convince others to agree to an opinion or opinion; (3) persuading others to start acting, such as buying a product or choosing a candidate in an organization selection; (4) to mediate the conflict in a matter. In this case, the argument has an important position in the speech activity; the better the argument is conveyed the more successful the message will be delivered by a speaker. Arguments are also also in the state speech as the dominant rhetoric used and the argument is the element that builds the state speech (Noermanzah, Emzir, \& Lustyantie, 2017:226).

There are several ways that can be used to analyze an argument, all of which are modifications of formal logic. One of them is by using Toulmin's argument structure. The structure of the Toulmen argument consists of six elements of argument, ie claim, ground, warrant, backing, qualifier, and possible (Syafi'e, 1998:97-98). (1) Claim is a statement that is believed to be true; (2) Ground (reason) serves as a support for the claim to be accepted and believed, in the form of reason, data, evidence used to support the statement presented as the basis of a claim; (3) Warrant is a statement of justification that shows the general principle, law or norm to defend claim; (4) Backing (support) is supporting evidence, supporting, supplementing ground to strengthen warrant; (5) Qualifiers/qualifications or qualifications are the ground restrictions on the warrants in order to correctly apply the claims correctly which indicates the degree of certainty or possibility of claim; and (6) Possible/rebbutal (denial) is a rebuttal to weaken or strengthen the claim

The argumentation model by Toulmin (in Renkema, 2004:203-204) is a model which can be used to analyze arguments on the use of everyday language or language in a particular event. In the Toulmin approach, the main thing is not the logical form of the argument but on how an argument is formed. According to Toulmin, the core argument is contained in three elements. They are claim, ground, and warrant. Three other elements of backing, qualifier, and possible can be used as needed or just as a supporter to understand the message presented.

\section{METHOD}

The research method was the critical discourse analysis method of Norman Fairclough model. The primary data of the research is rhetorical technique of argument contained in presidential speech of President of Republic of Indonesia Joko Widodo especially in education field. While secondary data in this research is oral text interview result to presidential speech compiler team (Minister of State Secretary and Segneg staff) about production of speech text of president, and oral text result of interview about expert opinion of education expert, principal, and teacher related contents speech texts and the impact of President Joko Widodo's speech on education in Indonesia. Then, the main data source of the study are two presidential speeches of President Joko Widodo, namely 1) Speech of the President of the Republic of Indonesia Towards the $71^{\text {st }}$ Birthday of the Republic of Indonesia at the Annual Joint Session of the House of Representatives and the DPD RI MPR/DPR-DPD Building; and 2) Speech Delivery of Government Description on the Draft of State Budget Revenue and Expenditure Budget and Financial Statements 2017 Budget Building MPR/DPR-DPD RI. Both of these speeches are conveyed in the MPR/DPR-DPD Building, Jakarta, August 16, 2016.

Data collection techniques used were documentation techniques, note-taking techniques, and interviews. Data analysis techniques was analyzed by linking micro, meso, and macro elements to dimensions: (a) text, (b) discourse practice, and (b) socio-cultural practices (Fairclough, 1995:9). The descriptive analysis is conducted in which to describe the content descriptively only on the level of text in the form of rhetorical technique of argument which will be analyzed assisted with data analysis table and recapitulation result to obtain general description of rhetorical argument technique used. In the discourse practice dimension, an intertextual analysis is necessary to relate the text analysis with discourse practice. This analysis was conducted simultaneously with text analysis, i.e. by examining how the text is produced and consumed by the people of Indonesia. At the production level of the text, we investigate the documents of President Joko Widodo's speech compiling, assisted by guidelines for research interviews. Then, the last step was conducted by analyzing the dimensions of socio-cultural practice by linking its analysis to the macro context.

\section{RESULTS AND DISCUSSION}

Presidential speech of President Joko Widodo or better known as Jokowi greeting has the uniqueness in presenting arguments based on the elements of the compiler or how an argument is formed in delivering educational programs. This uniqueness can be demonstrated by the use of varied argument techniques in the introduction, torso, and cover. In forming arguments President Joko Widodo is able to present it at least using the special claim element in the introduction and closing section. This is different from Toulmin's opinion that the core of the argument is in three elements, namely claim, ground, and warrant. The other three elements of backing, qualifier, and possible can be used as needed or just as a support to understand the message presented (Renkema, 2004:203-204). Thus, in the core speech the minimal argument has an element of claim, but in the introduction and closing. 
In forming arguments in the presidential speech, President Joko Widodo has the uniqueness in presenting his argument. The uniqueness of the rhetorical technique of argument contained in the State of President Jokowi's speech, especially for formal or formal speech, has techniques, namely 1) in the introduction using two patterns, namely: (a) claim and ground; and (b) claims. Claim in the introduction contains divine attitudes and prayer greetings (Muslim, common, Christian, Hindu, and Buddhist), greetings of honor to participants, thanksgiving, gratitude, apology, gratitude, and central themes. Ground contains explanation reasons. The following is an example of an official statement from President Jokowi's presidential speech in forming an argument with a claim and ground pattern in the introduction, especially on the Speech of the President of the Republic of Indonesia Submission of Government Statement of the State Budget Draft Law and the Financial Note of 2017 MPR/ DPR-DPD RI, held in Jakarta on August 16, 2016 compiled with the Presidential Expert Staff, Minister Segneg, Cabinet Secretary, and all related ministers.

Bismillahirrahmanirrahim,

Assalamualaikum warahmatullah wabarakatuh,

Selamat siang,

Salam damai sejahtera untuk kita semua,

Om swastiastu,

Namo buddhaya. (TRAJW-133)

Yang saya hormati Wakil Presiden Republik Indonesia, Yang saya hormati para Wakil Ketua dan para Anggota Dewan Perwakilan Rakyat Republik Indonesia,

Yang saya hormati Ketua, para Wakil Ketua, dan para Anggota Dewan Perwakilan Daerah Republik Indonesia, Yang saya hormati Ketua, para Wakil Ketua, dan para Anggota Lembaga-lembaga Negara,

Saudara-saudara sebangsa dan setanah air, Hadirin sekalian yang saya hormati. (TRAJW-134) Dengan penuh rasa syukur ke hadirat Tuhan Yang Maha Esa, siang ini kita dapat menghadiri Sidang Paripurna Dewan Perwakilan Rakyat Republik Indonesia dalam rangka penyampaian keterangan pemerintah atas Rancangan Undang-Undang Anggaran Pendapatan dan Belanja Negara serta Nota Keuangan Tahun Anggaran 2017. (TRAJW-135)

Atas nama pemerintah, saya mengucapkan terima kasih kepada semua Fraksi DPR RI atas berbagai masukan yang diberikan dalam pembicaraan pendahuluan beberapa waktu yang lalu. (TRAJW-136)

Dengan masukan-masukan itu, pemerintah dapat menyusun RAPBN Tahun 2017 yang semakin berkualitas. Insya Allah, apa yang kita usahakan bersama ini bermanfaat bagi seluruh rakyat, dan dapat menjadikan bangsa Indonesia sebagai bangsa pemenang dalam persaingan global, serta semakin mampu menjadi bangsa yang berdaulat dalam politik, berdikari dalam ekonomi, dan berkepribadian dalam berkebudayaan. (TRAJW-137)

From the excerpt of the presidential speech above, it can be explained that President Jokowi with his team formed an argument in the introduction by presenting some claims followed by the ground. The first Claim is TRAJW-133 in the form of opening prayer and opening prayer from various religions (Muslim, common, Christian, Hindu, and Buddhist), followed by claim on TRAJW-134 data in the form of honor to the participant's representative, followed by claims on TRAJW-135 data in the form of gratitude and the central theme of the speech, followed by claim on TRAJW-136 data in the form of gratitude to the House of Representatives Faction on various inputs on the contents of the speech to be delivered, and ending with ground on TRAJW- 137 in the form of claim-related information on the TRAJW-136 data. Claim formed by President SBY shows that his speech and the results of his performance is the result of a joint performance based on the aspirations or inputs of various elements of society which in this case is represented by all the factions of the House of Representatives. In this way, the participants felt as an integral part of the speech activities and played an important role equally with the government so that the patos arose in the form of a sense of belonging to the Indonesian people. Later, President Jokowi also formed an argument in the introduction using only a claim technique which indicates that he wanted to shorten the introduction because the essence of the introduction of a speech conveys the claim of a central theme. An argument technique that uses only the claim patterns in is shown in the following speech quotation.

Bismillahirrahmanirrahim,

Assalamualaikum warahmatullah wabarakatuh,

Selamat pagi,

Salam damai sejahtera untuk kita semua,

Om swastiastu,

Namo buddhaya. (TRAJW-99)

Yang saya hormati Ketua, para Wakil Ketua, dan para Anggota Dewan Perwakilan Rakyat Republik Indonesia, Yang saya hormati Ketua, para Wakil Ketua, dan para Anggota Dewan Perwakilan Daerah Republik Indonesia,

Yang saya hormati Ketua, para Wakil Ketua, dan para Anggota Lembaga-lembaga Negara,

Yang saya hormati Bapak BJ Habibie, Presiden Ketiga Republik Indonesia,

Yang saya hormati Ibu Megawati Soekarnoputri, Presiden Kelima Republik Indonesia,

Yang saya hormati Bapak Try Sutrisno,

Yang saya hormati Bapak Boediono,

Yang saya hormati Ibu Shinta Nuriyah Abdurrahman Wahid,

Yang saya hormati Yang Mulia para Duta Besar Negara-negara Sahabat dan para Pimpinan Perwakilan Badan serta Organisasi Internasional,

Saudara-Saudara sebangsa dan setanah air,

Hadirin sekalian. (TRAJW-100)

Marilah kita bersama-sama bersyukur ke hadirat Tuhan Yang Mahakuasa karena, atas karunia-Nya, kita dapat menghadiri Sidang Bersama Dewan Perwakilan Rakyat dan Dewan Perwakilan Daerah Republik Indonesia dalam rangka Peringatan Hari Ulang Tahun Ke-71 Proklamasi Kemerdekaan Republik Indonesia. (TRAJW-101)

From the speech quotation of the President of the Republic of Indonesia on the $71^{\text {st }}$ Independence Day of the 
Republic of Indonesia at the Annual Joint Session of the House of Representatives and the DPD RI MPR/DPRDPD House held in Jakarta on 16 August 2016, President Jokowi in his argument at the introduction official presidential speech only used argument techniques with multiple claim patterns. Claim opener on TRAJW-99 data in the form of individual prayer and prayer opening (Muslim, General, Christian, Hindu, and Buddhist), followed by claim on TRAJW-100 data in the form of honor to each representative of participants starting from vice president followed by state high institutions starting from the highest institutions such as the House of Representatives, all of peoples, audiences who can not be mentioned one by one, and then it ended with a claim on TRAJW-101 data in the form of gratitude and the central theme of the event Joint Meeting of DPR and DPD RI in the $71^{\text {st }}$ NKRI Anniversary as the primary claim in the introduction of a presidential speech.

Furthermore, 2) in the body or content, President Jokowi and his team are also skilful in forming the arguments, it was proved by the use of argument variation techniques with several patterns, namely: (a) claim and ground; (b) claim, ground, and claim; (c) claim, ground, and warrant; (d) claim, ground, and possible; and (e) claim, ground, warrant and backing with each sub topic or argument, minimally and dominantly comprising claim and ground. Claim in the torso contains: attitude, opinion, hope. Ground contains: material science reasons, evidence of statistical and non-statistical data, performance analysis, motivation, examples, experiences, policies, and information. Warrant contains: the principle of law and general rules. Backing contains supporting data rules and experience. Possible on the torso contains a reinforcing and debilitating claim. An example of using argument techniques using claim and ground patterns in official presidential speech of President Jokowi is as follow.

Selanjutnya, dalam membangun manusia Indonesia yang berkualitas, produktif, dan berdaya saing, kita tingkatkan kualitas pembangunan di sektor kesehatan, pendidikan, dan jaminan sosial. (TRAJW-120)

Di sektor kesehatan, Program Indonesia Sehat yang memiliki tiga pilar. Pertama, penerapan paradigma sehat. Kedua, penguatan pelayanan kesehatan. Ketiga, pelaksanaan Jaminan Kesehatan Nasional (JKN). Berdasarkan data BPJS Kesehatan per Juli 2016, peserta JKN sudah mencapai hampir 170 juta jiwa. Jumlah sarana pelayanan yang bekerja sama dengan BPJS Kesehatan juga terus meningkat. Di sektor pendidikan, sekarang ini sedang dilakukan percepatan pembagian Kartu Indonesia Pintar di seluruh pelosok tanah air. Perhatian pemerintah terutama diberikan kepada anak usia sekolah 6-21 tahun dari keluarga tidak mampu. Melalui KIP, diberikan jaminan untuk mendapatkan layanan pendidikan dasar sampai menengah, pendidikan formal dan nonformal, termasuk untuk mendapatkan keterampilan dari lembaga kursus/BLK.

Selain itu, juga sosialisasi nilai-nilai keutamaan dan pendidikan karakter pada anak didik. Pemerintah juga berusaha untuk meningkatkan kesejahteraan guru yang mengabdi di daerah-daerah terpencil, pulau-pulau terdepan, dan wilayah-wilayah perbatasan. (TRAJW-121)

From the above quote example, the presentation of argument about education program is done by presenting claim on TRAJW-120 data in the form of opinion of how to improve a qualified Indonesian human that is through education. Then, continued with the ground on TRAJW-121 data in the form of information on government programs in the field of health and education. President Jokowi in explaining the importance of education provides the power of argument through the socialization program of values of virtue and character of education in the students and the improvement of the welfare of teachers who serve in remote areas, the outlying islands and border areas. This shows that President Jokowi's education principle is socialized and prioritizes the need for education in areas that are in desperate need of attention which has not been so gaining attention.

President Jokowi's excellence is to show his side to the weak people. Nevertheless, the explanation of the education program is not yet explained in detail how the implementation is, especially in the socialization of character education and teacher welfare improvement programs in the outermost and remote areas. This also shows that Jokowi's argument technique is short and does not really need imaging because it assumes that people will know their own performance through other media such as instantly feel the impact, through television media, newspaper, facebook, twitter, radio, and others. Although in fact, there are still many teachers who live in developing provinces and cities are still not prosperous, for example, from the salary interviews of teachers there are still only 300 thousand rupiah per month. This is in Warburton's opinion (2016:317) explains that President Jokowi as a new order product prioritizing infrastructure improvement programs and public service provision is also true. Although many educational programs are being run, they have not fully impacted the significant improvement in the quality of education.

President Jokowi and his team are also good at presenting arguments in the body of the presidential; speech by using claim, ground, and claim patterns. As in the following speech quotation example.

Pimpinan dan Anggota Dewan yang saya muliakan,

Dengan mengacu pada tema kebijakan fiskal tahun 2017 dan strategi yang mendukungnya, pendapatan negara dalam RAPBN 2017 ditargetkan sebesar Rp 1.737,6 triliun. (TRAJW-148)

Dari jumlah tersebut, penerimaan perpajakan direncanakan sebesar Rp 1.495,9 triliun. Selanjutnya, Penerimaan Negara Bukan Pajak (PNBP) di tahun 2017, meskipun menghadapi tantangan yang cukup berat dengan masih rendahnya harga beberapa komoditas pertambangan seperti minyak bumi dan batu bara, ditargetkan sebesar Rp 240,4 triliun.

Sementara itu, belanja negara dalam RAPBN Tahun 2017 dialokasikan sebesar Rp 2.070,5 triliun, yang terdiri dari belanja Pemerintah Pusat sebesar Rp 1.310,4 triliun dan alokasi Transfer ke Daerah dan Dana Desa 
sebesar Rp 760 triliun. (TRAJW-149)

Dengan berbagai agenda dan sasaran pembangunan yang saya sampaikan tadi, maka kebijakan fiskal dalam tahun 2017 masih bersifat ekspansif yang terarah untuk meningkatkan kapasitas produksi, dengan defisit anggaran RAPBN 2017 ditargetkan sebesar Rp 332,8 triliun atau 2,41\% dari PDB. (TRAJW-150)

Secara umum, kebijakan pembiayaan anggaran tahun 2017 akan diarahkan untuk mengembangkan dan mengoptimalkan pembiayaan kreatif dan inovatif, sekaligus meningkatkan akses pembiayaan bagi UMKM, membuka akses pembiayaan pembangunan dan investasi secara lebih luas, mendukung program peningkatan akses pendidikan dan penyediaan rumah bagi masyarakat berpenghasilan rendah, serta menyempurnakan kualitas perencanaan investasi pemerintah, dan rasio utang terhadap PDB dalam batas aman dan terkendali. Selain itu keterlibatan pihak swasta dalam pembiayaan pembangunan akan ditingkatkan melalui skema kerja sama antara pemerintah dan badan usaha. (TRAJW-151)

The quote of President Jokowi speech above shows its uniqueness in using argument technique with claim, ground and claim pattern which is located at the end of the body or content section. Then, the claim on the TRAJW-148 data is an opinion on the target of state income, followed by ground on TRAJW-149 data in the form of information with statistical data on how to obtain state revenue, and ended with two claims, the first claim on TRAJW-150 data opinion on the nature of physical policies 2017 and claims on TRAJW-151 data in conclusion of 2017 budget financing including budget financing for education.

In explaining the financing of the education, President Jokowi prioritized in supporting the program to improve access to education. However, it did not explain what kind of access to education so that the audiences did not really understood the educational objectives undertaken by President Jokowi. In particularly, related to the constitution Number 202003 regarding National Education System law subsection 5 verse 1, namely "Every citizen has the same right to obtain qualify education". Then, law subsection 11, paragraph 1 which states that: "The Government and the Regional Government obligate to provide services and convenience, and ensure the implementation of qualify education for every citizen without discrimination". As president should provide a more comprehensive argument in explaining the role and duty of the government in improving the quality of education not only to improve access to education in budget planning. Especially when we refer to the 1945 Constitution which gives a mandate to the government that every citizen is entitled to get education to improve the quality and welfare of his life. Indeed, if this mandate is run by the central and local governments, Indonesia may rapidly advance, not only in education, but in economics and others sectors because the key to the development of a country is education.

Then, President Jokowi is also skilful in forming arguments by using claim patterns, ground, and warrant in his official presidential speech. This can be shown in the following speech quotation.
Hadirin yang saya muliakan,

Sebagai katalisator pembangunan infrastruktur fisik dan sosial, pemerintah berkomitmen melakukan deregulasi dan debirokratisasi. (TRAJW-122)

Banyak regulasi kita sudah usang, sudah harus diperbaharui untuk menyongsong perubahan zaman. Maka, regulasi yang membingungkan harus disederhanakan. Prosedur yang rumit harus dipangkas. Deregulasi dan debirokratisasi itu kita lakukan untuk memberikan kecepatan pelayanan, kepastian, sinkronisasi, kemudahan berinvestasi, serta meningkatkan produktivitas. Wujud nyata adalah 12 paket kebijakan ekonomi yang telah dikeluarkan pemerintah sampai dengan awal Juni 2016. Dari 12 paket ekonomi tersebut, dapat saya sampaikan bahwa $96 \%$ perangkat regulasinya sudah selesai disiapkan.

Guna mempercepat manfaat dari paket-paket itu, telah dibentuk Satuan Tugas Percepatan dan Efektivitas Pelaksanaan Kebijakan Ekonomi pada tanggal 28 Juni 2016. Ke depan, diupayakan pembentukan paket kebijakan ekonomi lainnya guna mempercepat peningkatan ekonomi nasional.

Sebagai bagian dari deregulasi, pemerintah telah mengsinkronkan berbagai peraturan daerah (perda) terkait perdagangan dan investasi. Lebih dari 3.000 perda sudah dibatalkan karena tidak kondusif bagi kemajuan perdagangan dan kemudahan berusaha.

Mencermati berbagai kesalahpahaman tentang pembatalan perda, saya tegaskan dua hal. Pertama, sinkronisasi perda dilakukan untuk kepentingan nasional, yang artinya termasuk kepentingan daerah. Sinkronisasi yang telah dilakukan akan membawa manfaat bagi daerah dalam menarik investasi dan menciptakan lapangan kerja. Kedua, perda yang dibatalkan hanya terkait urusan perdagangan dan investasi. (TRAJW-123)

Sinkronisasi dilakukan agar ada keselarasan, agar ada kesinambungan regulasi dari Undang-Undang Dasar 1945 dengan beragam regulasi di tingkat pusat hingga daerah. Tidak ada peraturan pemerintah, baik di tingkat pusat maupun daerah, yang berada di atas Undang-Undang Dasar 1945. Semuanya harus berada di bawah konstitusi, di bawah kehendak rakyat. (TRAJW-124)

From the above data, government is committed to deregulation and debureaucratization both at the central and regional levels or between the central and regional governments. The term of deregulation is an activity or process in eliminating or reducing a rule while the bureaucracy as a process in reducing the rules of working procedures which are always leisure and complicated in achieving faster results. Both of these terms arise because Indonesia embraces the democratic system so that the derivation of the term bureaucracy derived from the word bureucracy which means the administration is identified by compliance with rules, procedures, and levels of authority resulting in inaction, the complexity of the acquisition of a result, and the occurrence of delay motion. President Jokowi with his sudden visit method and his experience as governor of DKI Jakarta and the mayor of Solo, understands the problems of existing regulations in central 
and local government so it becomes important to deregulate and debirokratisasi, unfortunately Jokowi government has not focused to make changes in the rules of education. For example, senior high school teachers are administered under the provincial service so that instead of speeding up the affairs of teachers, it slows teachers' matters. Not to mention at the college level, under the command of the Ministry of Research and Technology Dikti, state universities in the region must take care of everything directly to the center so it takes a long time and procedure so much, not to mention private universities that must through Kopertis region before entered the Ministry of Research and Technology Dikti especially in kepengururan functional promotion to the head and professor. This should be conveyed by President Jokowi in his speech so that it can assist in improving and accelerating the progress of primary, secondary, and higher education.

President Jokowi is also good at forming arguments in his presidential speech especially in the body section of speech, that is by using claim patterns, ground, and possible. The proof of a quote using the pattern is as follow.

Pimpinan dan Anggota Dewan yang saya muliakan,

RAPBN Tahun Anggaran 2017 disusun di atas fondasi apa yang telah kita capai pada tahun 2015 dan perkembangan faktual pada tahun anggaran 2016. (TRAJW-138)

Pada tahun 2015, kita telah membangun fondasi dengan melakukan transformasi fundamental perekonomian nasional. Paradigma pembangunan yang bersifat konsumtif kita ubah menjadi produktif. Selain itu, kita juga mulai meletakkan paradigma Indonesia-sentris, di mana pembangunan tidak hanya dilakukan di Pulau Jawa tetapi merata di seluruh tanah air. Tanpa keberanian melakukan lompatan paradigma tersebut, kita tidak akan pernah bisa meletakkan fondasi pembangunan nasional yang kuat dan kokoh.Selanjutnya, saat memasuki tahun 2016, pemerintah ingin bergerak lebih cepat dengan mencanangkan tahun 2016 sebagai tahun percepatan pembangunan. Langkah percepatan itu dilakukan antara lain melalui percepatan pengadaan barang dan jasa, yang telah dimulai pada triwulan keempat sebelum tahun anggaran berjalan. Selain itu, percepatan juga dilakukan melalui pembentukan Badan Layanan Umum Lembaga Manajemen Aset Negara sebagai upaya percepatan penyediaan tanah untuk pembangunan infrastruktur.

... Indikator kesejahteraan sosial Indonesia dalam dua tahun terakhir ini juga terus menunjukkan peningkatan. Data pada Maret tahun 2016 menunjukkan tingkat kemiskinan berhasil ditekan menjadi 10,86 persen. Tingkat ketimpangan yang ditunjukkan oleh Gini Ratio juga berhasil dikurangi menjadi 0,40. Dan tingkat pengangguran berhasil diturunkan menjadi 5,5\%. Sementara, Indeks Pembangunan Manusia yang menunjukkan akses masyarakat terhadap sumber ekonomi, pendidikan, dan kesehatan terus mengalami kemajuan hingga mencapai angka 69,55 pada tahun 2015. (TRAJW-139)

Namun demikian, perlu disadari bahwa kita masih akan menghadapi tantangan-tantangan berat ke depan. Belum pulihnya perekonomian global dan beberapa negara mitra dagang utama, yang diiringi masih rendahnya harga komoditas, masih menjadi risiko yang dapat mengganggu kinerja perekonomian nasional. Di samping itu, negara-negara maju juga sedang bergulat menghadapi tantangan pemulihan ekonomi sehingga masih terdapat ketidakpastian kebijakan keuangan, termasuk sebagian negara menerapkan kebijakan penggelontoran likuiditas. (TRAJW-140)

From the above speech quotation, explains that President Jokowi formed the argument with the claim pattern on TRAJW-138 data in the form of opinion on the drafting of RAPBN 2017, ground on TRAJW-139 data in the form of information with science, policy, statistical data and sample, possible on the TRAJW-140 data aims to weaken the claim. President Jokowi especially in conveying the pattern of possible indicates that the Government has the nature or ethics (ethos) humble which previously provided ground in the form of improvement in various fields including education. It is in Sabrina's opinion (in Shabani 2018: 20) that ethos as part of persuasive technique refers to the credibility of the communicator so as to reveal the source confidence and add value to the claim. However, there are other meanings because the possibility of weakening the claim may mean that the Government is looking for ways to deal with increasingly complicated global challenges, for example as proven now by rising fuel prices, rising electricity prices, creating education of BLU, schools are allowed to charge monthly school committees fees. Moreover, Jokowi's government debt is now quite fantastic in number because of the promise of a major campaign to create access toll roads, trains, airports, and sea toll access. Hopefully the government can work optimally in managing the country's debt by deregulation and debureaucratation techniques in every regulation. Hopefully, the government can deal with the mental attitude namely the mental attitude or the character of policy actors and companies that are still doing corruption, collusion, and nepotism in every field, including in the field of education.

A unique argument technique is also presented by President Jokowi in his official speech by using claim patterns, ground, warrant and backing. This can be shown in the following speech quotation.

Hadirin yang saya muliakan,

Pada tahun percepatan pembangunan ini, pemerintah fokus pada tiga langkah terobosan untuk pengentasan kemiskinan, pengangguran, ketimpangan dan kesenjangan sosial. Ketiga langkah itu adalah:

Yang pertama, percepatan pembangunan infrastruktur. Yang kedua, penyiapan kapasitas produktif dan sumber daya manusia.

Ketiga, deregulasi dan debirokratisasi. (TRAJW-112)

Melalui percepatan pembangunan infrastruktur, kita bangun sarana infrastruktur secara lebih merata di seluruh tanah air guna memperkuat konektivitas antarwilayah dan memperkecil ketimpangan dan kesenjangan sosial. Akselerasi pembangunan infrastruktur logistik meliputi jalan nasional dan jalan tol, jembatan, jalur kereta api, tidak hanya di Pulau Jawa tapi juga di Pulau Sumatera, di Kalimantan, di Sulawesi, dan juga dibangun mass 
rapid transportation (MRT), light rail train (LRT), dan commuter line, pelabuhan sebagai perwujudan program tol laut, dan juga bandara. Sedangkan akselerasi pembangunan infrastruktur strategis mencakup pembangkit listrik, waduk, telekomunikasi, dan perumahan rakyat. Percepatan pembangunan infrastruktur tersebut, baik infrastruktur logistik maupun infrastruktur strategis, tentu saja tidak melupakan kelestarian alam. Pemenuhan target rasio kelistrikan juga mengutamakan penggunaan energi baru dan terbarukan. Selain itu, juga dilakukan percepatan pembangunan waduk dan embung untuk memperkuat program ketahanan air.

Bersamaan dengan pembangunan infrastruktur yang mengedepankan kelestarian alam itu, pemerintah melakukan konservasi lahan gambut dan pencegahan pembakarannya. Pemerintah tidak menoleransi pelaku pembakaran lahan gambut dan hutan karena tindakan itu termasuk kejahatan kemanusiaan. (TRAJW-113)

Saudara-Saudara sebangsa dan setanah air,

Dalam percepatan pembangunan infrastruktur, pemerintah berkewajiban untuk membangun wilayah-wilayah yang marginal, wilayah-wilayah yang tertinggal dengan menggunakan dana APBN. Sedangkan terhadap daerah-daerah lain yang ekonominya menggeliat dan tumbuh, pemerintah mendorong peran dunia usaha dan kerja sama dunia usaha dengan BUMN. Nilai investasi BUMN akan terus kita perbesar. (TRAJW-114)

Selain itu, dengan dukungan DPR, pemerintah melakukan teroboson dengan mengeluarkan aturan tentang amnesti pajak. Diharapkan basis penerimaan pajak menjadi semakin luas guna mempercepat pembangunan dan meningkatkan daya saing nasional. (TRAJW-115)

From the above speech quotes, it can be explained that President Jokowi used argument techniques with the pattern of claim on TRAJW-112 data in the form of government by overcoming poverty, unemployment, inequality and social inequality. Followed by ground on TRAJW-113 data in the form of reason with description and data. Then, followed by warrant on the TRAJW-114 data in the form of legal principle of government obligation and ending with backing on TRAJW-112 data in the form of supporting data as a complementary ground to strengthen warrant in the form of tax amnesty rules. Unfortunately argument techniques with claim patterns, ground, warrant and backing do not specifically address education programs. Jokowi government seems more interested in increasing state revenues in the field of taxation rather than improving the quality of education in order to increase state revenues.

Then, 3) in the closing section, President Jokowi used the argument technique with two patterns, namely: (a) claim, ground, and claim; (b) claim. Claim in the closing section contains: an attitude of hope, appreciation, prayer of hope, survival, closing, thanksgiving \& closing prayers (common, Muslim, Hindu and Buddhist). The element of ground on the cover contains the reasons for the description of science materials and motivation for real work. Here is an example of how President Jokowi quote in forming arguments by using claim, ground, and claim patterns.

Hadirin yang saya muliakan,
Di akhir pidato kenegaraan di depan sidang terhormat, saya mengajak segenap elemen bangsa untuk bersinergi mengatasi kemiskinan, mengatasi pengangguran, serta mengatasi ketimpangan dan kesenjangan sosial.(TRAJW-129)

Tanpa kerja sama, tanpa gotong royong, kita akan digulung oleh arus sejarah. Kita tidak menginginkan itu. Oleh sebab itu, apa pun bidang yang Saudara-Saudara geluti, jadilah yang terbaik.Dengan kerja nyata, bangsa Indonesia bisa menjadi bangsa pemenang. Dengan kerja nyata, bangsa Indonesia bisa menjadi bangsa maju, menjadi bangsa yang berdaulat, mandiri, dan berbudaya. Sekarang ini biduk kita sedang berlayar menuju ke sana, menuju kemajuan Indonesia Raya! (TRAJW-130)

Dirgahayu Republik Indonesia!

Dirgahayu Negeri Pancasila!

Merdeka! Merdeka! Merdeka! (TRAJW-131)

Terima kasih.

Wassalamualaikum warahmatullah wabarakatuh,

Om shanti shanti shanti om,

Namo buddhaya. (TRAJW-132)

From the closing quote of the Speech in the $71^{\text {st }}$ Anniversary of the Republic of Indonesia at the Annual Joint Meeting of the House of Representatives and the DPD RI at the MPR/DPR-DPD Building on $16^{\text {th }}$ of August 2016, we can see that President Jokowi and his team form some arguments by using a fairly interesting pattern, the pattern that begins with the claim in the TRAJW-129 data in the form of expectation to the community to work together, clarified with ground in TRAJW-130 data in the form of material science and motivation for real work, ending with two claim the first claim in the TRAJW-131 data in the form of an appreciation of Indonesia's independence and a second claim in TRAJW-132 data in the form of a closing terima kasih, and a prayer closing (Muslim, Hindu and Buddhist). The pattern of closing in this official speech can be used as a model in formulating an official speech especially in the context of independence day celebration or any other celebrations.

Moreover, President Jokowi and his team also formed an argument in the closing section of his official presidential speech by using a claim pattern as the following speech quotation.

Saudara Ketua, para Wakil Ketua, dan para Anggota DPR RI,

Saudara Ketua, para Wakil Ketua, dan para Anggota Lembaga-Lembaga Negara,

Saudara-Saudara sebangsa dan setanah air,

Demikianlah penjelasan saya mengenai Pokok-Pokok RAPBN Tahun 2017. Saya berharap pembahasan RUU tentang APBN serta Nota Keuangan Tahun 2017 dapat berjalan lancar dan tepat waktu. Saya berkeyakinan, dengan kepercayaan dan dukungan rakyat, pemerintah dapat bekerja lebih baik, bekerja lebih efektif dalam mencapai kemajuan bersama. (TRAJW-152)

Semoga Tuhan Yang Maha Esa selalu bersama kita semua, untuk berjuang mewujudkan Indonesia sebagai negara maju, menjadi bangsa pemenang yang berdaulat secara politik, berdikari di bidang ekonomi, dan 
berkepribadian dalam kebudayaan. (TRAJW-153)

Dirgahayu Republik Indonesia!

Dirgahayu Negeri Pancasila! (TRAJW-154)

Wassalamualaikum warahmatullah wabarakatuh,

Om shanti shanti shanti om,

Namo buddhaya. (TRAJW-155)

From the quotation above, in forming arguments in the closing section of official speeches, claim patterns can be used as well. Claim formed consists of four claims, the first claim on TRAJW-152 data in the form of expectations about the implementation of RAPBN 2017, RUU APBN and Finance Bill 2017; the second claim to TRAJW-153 data is an attitude of expectation of prayer to God YME; the third claim on TRAJW-154 data is a survival; and the fourth claim on TRAJW-155 data is an acknowledgment of greetings and closing prayers (Muslim, Hindu, and Buddhist). By this argument technique, it indicates that President Jokowi and his working team wish to show that the results of their performance in government is the works of all society members because Indonesia is based on democracy. Then, it is important to show that President Jokowi is religious based on Pancasila with the cultural diversity which appear in the closing prayer contains several religions that are sorted according to the number of adherents. Although there are some religions that have not been represented in the closing greetings, such as Protestant, Catholicism, and $\mathrm{Khon} \mathrm{Hu} \mathrm{Cu}$ (Confucius).

\section{CONCLUSUION}

The rhetorical techniques structured in the presidential speech by President SBY and Jokowi in the reform era in the field of education use some pattern of argument particularly for formal speech using argument pattern based on the parts of the speech i.e.: 1) the introduction has two patterns: (a) claim and ground; and (b) claim. Claim in the introduction contains divine attitudes and prayer greetings (Muslim, General, Christian, Hindu, and Buddhist), greetings to the participants, thanksgiving, gratitude, apology, gratitude, and central themes. Ground contains explanation reasons. 2) body section has a pattern: (a) claim and ground; (b) claim, ground, and claim; (c) claim, ground, and warrant; (d) claim, ground, and possible; and (e) claim, ground, warrant and backing with each sub topic or argument, minimally and dominantly comprising claim and ground. Claim in the torso contains: attitude, opinion, hope. Ground contains: material science reasons, evidence of statistical and non-statistical data, performance analysis, motivation, examples, experiences, policies, and information. Warrant contains: the principle of law and general rules. Backing contains: data support rules and experience. Possible on the torso contains a reinforcing and debilitating claim. 3) The closing section has a pattern: (a) claim, ground, and claim; (b) claim. Claim in the closing section contains: an attitude of hope, appreciation, prayer expectancy, congratulations, a sign of closing gratitude \& closing prayers (common, Muslim, Hindu and Buddhist). The element of ground in the closing contains the reasons for the description of knowledge and motivation for concrete works.
Variants rhetorical techniques in organizing the arguments in the Presidential speeches of the Republic of Indonesia in education are the result of teamwork between President and Presidential Expert Staff, Cabinet Secretary, Ministry of Education and Culture, Ministry of Research and Technology of Dikti, and ministries related to speech themes, parties related to the theme of the speech. The variation of rhetorical technique in argument used by President Joko Widodo aims to convey the plan of work programs, work programs that have been done, and promise to run the programs particularly in education to the people of Indonesia. Then, the variation of rhetorical techniques in this argument can be used as an example for speech writing, both in junior high school, senior high school, and at university level especially for official speech.

\section{ACKNOWLEDGEMENTS}

The authors would like to thank the Ministry of State Secretariat of the Republic of Indonesia, National TVRI, Indonesian education experts, and teachers who have been concerned to provide data and information related to research data.

\section{REFERENCES}

Altikriti, S. (2016). Persuasive speech acts in Barack Obama's inaugural speeches $(2009,2013)$ and the last state of the union address (2016). International Journal of Linguistics, 8 (2): 63. http://dx.doi.org/10.5296/ijl. v8i2.9274

Aydoğan, H., \& Akbarov, A. A. (2014). The four basic language skills, whole language \& intergrated skill approach in mainstream university classrooms in Turkey. Mediterranean Journal of Social Sciences, 5(9), 673. Doi:10.5901/mjss.2014.v5n9p672

Crusius, T.W. \& Channel, C.E. (2003). The aims of argument: a text and reader, $4^{\text {th }}$ edition. New York: The McGraw-Hill Company.

Eriyanto, R. (2000). Kekuasaan otoriter dari gerakan penindasan sampai menuju politik hegemoni. Yogyakarta: Insist.

Fairclough, N. (1995). Critical discourse analysis: the critical study of language. London and New York: Longman.

Hamilton, Ch. (2012). Essentials of public speaking, fifth edition. USA: Wadsworth.

Jupriono, D. (2010). Analisis wacana kritis latar historis pidato kenegaraan Presiden Susilo Bambang Yudhoyono. Parafrase, 3 (2): 38-39.

McCrimmon, J. M. (1984). Writing with a purpose. New Jersey: Houghton Mifflin Company.

Noermanzah. D. (2016). Sermon rhetoric patterns of President Joko Widodo's oration in the occasion of Bung Karno's oration on June 1, 1945 commemoration. Journal of Indonesian Language Education and Literary (JILEL), 1 (2): 22-23.

Noermanzah, E., \& Lustyantie, N. (2017). Variety of rhetorics in political speech President of the Republic of Indonesia Susilo Bambang Yudhoyono and Joko Widodo 
in educational field. Humanus: Jurnal Ilmiah Ilmu-Ilmu Humaniora, 16(2), 221-238. https://doi.org/10.24036/ humanus.v16i2.8103

Nur, Agustiar Syah. (2001). Perbandingan sistem pendidikan 15 negera. Bandung: Lubuk Agung Bandung.

Rakhmat, J. (2009). Retorika modern: pendekatan praktis. Bandung: PT Remaja Rosdakarya.

Rakhmat, J. (2014). Retorika modern pengantar pertama retorika modern: sebuah kerangka teori dan praktik berpidato. Bandung: Angkasa.

Renkema, J. (2004). Introduction to discourse studies. Amsterdam: John Benjamins Publishing Company.

Ricky, H. (2014). Perbandingan retorika Prabowo Subianto dan Joko Widodo dalam debat calon presiden 2014 (Studi kasus retorika debat calon presiden 2014 mengenai pembangunan ekonomi dan kesejahteraan sosial). Retrieved from http://e-journal.uajy.ac.id/6444

Shabani, S. (2018). Persuasive strategies towards racial appeal in Tony Morrison's the bluest eye. International Journal of Applied Linguistics and English Literature (IJALEL), 7 (1): 20. http://dx.doi.org/10.7575/aiac.ijalel.v. 7 n. $1 \mathrm{p} .19$

Syafi'e, I. (1998). Retorika dalam menulis. Jakarta: Depdikbud, Dikti.

Warburton, E. (2016). Jokowi and the new developmentalism. Bulletin of Indonesian Economic Studies, 52 (3): 317. https://doi.org/10.1080/00074918.2016.1249262

Winkler, A. C., \& McCueen, J.R. (1974). Rhetoric made plain: third edition. New York: Harcourt Brace Jovanovich, Inc. 